\title{
Effect of sprouting in physico-chemical properties of tofu
}

\begin{abstract}
The effect of sprouting of soybean on the yield, proximate composition and sensory quality of tofu were studied to assess the feasibility of using sprouting as a non-chemical, nonthermal tool to improve quality of tofu. Tofu was prepared from sprouted, unsprouted and combination of both sprouted and unsprouted seeds in equal proportion. Product from sprouted varieties showed increased crude protein and crude fiber i.e. $44.73 \pm 1.34 \%$ and $11.98 \pm 0.71 \%$ respectively. Fat, ash and carbohydrate was however found to decrease on germination. From the sensory evaluation, sprouted tofu got highest mean sensory score. Aroma of sprouted tofu was highly accepted. The yield \% of tofu samples were also calculated and were found to be $42.33 \%, 37.69 \%$ and $39.70 \%$ for regular, sprouted and combined tofu respectively. From the sensory evaluation, sprouted and combined tofu was selected for further analysis and both types were prepared by varying the coagulation temperature i.e. $75^{\circ} \mathrm{C}$ and $90^{\circ} \mathrm{C}$. The yield $\%$ of sprouted and combined tofu prepared at $90^{\circ} \mathrm{C}$ was found to increase significantly $(\mathrm{p}>0.05)$. The proximate composition varied slightly with increase in coagulation temperature. Minerals content (calcium and iron) decreased significantly $(\mathrm{p}>0.05)$ with increase in temperature. Similarly, phytic acid and oxalate content in tofu decreased with increase in coagulation temperature.
\end{abstract}

Keywords: tofu, sprouting, coagulation temperature
Volume I Issue 2 - 2014

Pravin Ojha,Tika B Karki, Shreejana Maharjan

National College of Food Science and Technology, Nepal

Correspondence: Pravin Ojha, National College of Food Science and Technology, Affiliated to Tribhuwan University, Khusibu, Nayabazar, Kathmandu, Nepal,Tel 9779851023022, Email projha84@gmail.com

Received: April 25, 2014 | Published: May 24, 2014

\section{Introduction}

Tofu is a soymilk curd production made through a non-fermented process from soymilk. ${ }^{1}$ It is a highly versatile and nutritious food that is made from soybean curd. Although the word "tofu" is Japanese, the food seems to have originated in ancient China, where the Mandarin term is doufu. ${ }^{2}$ It is one of the most important and popular traditional food products in most East and Southern Asian countries. With respect to nutrition, tofu is cholesterol free, low in saturated fat and high in protein. $^{3}$

Tofu, also known as soybean curd, is a soft, cheese like food made by curdling fresh hot soymilk with a coagulant. It is produced traditionally by curdling fresh hot soymilk with either $\left(\mathrm{CaCl}_{2}\right.$ or $\mathrm{CaSO}_{4}$ ) or an acid (glucono- $\delta$-lactone). The coagulant produces a soy protein gel, which traps water, soy lipids and other constituents in the matrix forming curds. The curds are then pressed into solids. ${ }^{2}$ It is an inexpensive, nutritious and versatile meat or cheese substitute with bland taste and porous texture. On the moisture free basis, tofu contains about $50 \%$ protein and $27 \%$ oil and the remaining constituents are carbohydrate and minerals. It is cholesterol free, rich source of protein, minerals and poly unsaturated fatty acid. Therefore tofu can form an alternative protein source, which is higher than soybean (on dry basis). Several processing factors affect the quality and texture of tofu, such as cultivar of soybean, processing methods and type of coagulants. ${ }^{4}$

Sprouting is the practice of soaking and leaving seeds until they germinate and begin to sprout. This practice is reported to be associated with improvements in the nutritive value of seeds. At the same time there are indications that germination is effective in reducing phytic acid and flatulence causing oligosaccharides (namely stachyose and raffinose), thereby increasing protein digestibility and increasing sensory properties. ${ }^{5}$ Sprouting is known to reduce undesirable flavors such as beany and grassy to a minimum and maximize total acceptability for the soymilk prepared from soybeans germinated for two days as well as in rotted nutty odor and taste.

Several studies on the effect of germination on legumes found that germination can increase protein content and dietary fiber; reduce tannin and phytic acid content and increase mineral bioavailability. Germination also was reported to be associated with increase of vitamin concentration and bioavailability of trace elements and minerals. ${ }^{6}$ Kaushik et al., ${ }^{7}$ found that germination improves calcium, copper, manganese, zinc, riboflavin, niacin and ascorbic acid content.

\section{Materials and methods}

Firstly the raw soybeans (yellow variety) were collected from the Kathmandu valley, Nepal.

\section{Preparation of regular tofu}

$200 \mathrm{~g}$ of yellow soybean was taken separately for each of the tofu variety and were soaked separately for $12 \mathrm{~h}$. The swelled beans were dehulled manually and ground by means of a grinder. Grinding was done with intermittent addition of water. The bean to water ratio was maintained at 1:10 by adding water. The mash was heated and boiled for 3 minutes and filtered through muslin cloth.

The temperature of milk was lowered to $75^{\circ} \mathrm{C}$. Then the calcium chloride $(1.5 \%)$ was added as described above with continuous stirring until the addition was complete. The curd was transferred to the pressing box lined with muslin cloth. ${ }^{1}$

\section{Preparation of sprouted tofu}

Sprouting of soybean: Soybean seeds were cleaned thoroughly and made free from dust, dirt, stubbles and foreign matter. Seeds were soaked in tap water for $12 \mathrm{~h}$ at room temperature (RT). Then the excess 
water was drained and sample was further rinsed with tap water. Seeds were placed in a single layer on muslin cloth and placed in $\mathrm{RH}$ Chamber at the $25^{\circ} \mathrm{C}, 90 \% \mathrm{RH}$ for $72 \mathrm{~h}$ as per the method of. ${ }^{8}$

Preparation of soymilk tofu making: For the preparation of soymilk and tofu same process was repeated as for the regular tofu. ${ }^{1}$

\section{Preparation of combined tofu}

For the preparation of combined tofu, non-germinated and germinated soybean was combined in equal proportion (1:1) and the whole process was repeated as described above. ${ }^{1}$

On the basis of sensory evaluation, sprouted and combined tofus were selected for further processing and analysis. Thus, sprouted and combined tofus were prepared by varying coagulation temperature i.e. at $75^{\circ} \mathrm{C}$ and $90^{\circ} \mathrm{C}$.

Preparation of sprouted tofu: Sprouted soybean prepared as discussed above was used for tofu making as described by Fukushima $\mathrm{D}^{1}$ Two products by varying coagulation temperature $\left(75^{\circ} \mathrm{C}\right.$ and $\left.90^{\circ} \mathrm{C}\right)$ were prepared.

\section{Chemical analysis}

All raw materials and processes products were immediately analyzed in laboratory of NCFST, Kathmandu, Nepal. Proximate composition, Iron content and calcium content were determined according to the method of Ranganna. ${ }^{9}$

\section{Anti-nutritional factors}

Oxalate content was determined as per Patail and Gaidwad. ${ }^{10} 1 \mathrm{~g}$ oven dried sample along with $10 \mathrm{ml} 3 \mathrm{~N} \mathrm{HCl}$ and $65 \mathrm{ml}$ distilled water was taken in $100 \mathrm{ml}$ volumetric flask and boiled for $1 \mathrm{~h}$. After cooling the sample was diluted to $100 \mathrm{ml}$ and filtered. Two aliquots of $50 \mathrm{ml}$ extract with $20 \mathrm{ml} 6 \mathrm{NHCl}$ were evaporated to half and filtered by washing several times. To filtrate 3-4 drops of methyl red indicator was added and to this concentrated ammonia solution was added until the solution turned faint yellow. The solution was heated on water bath $90-100^{\circ} \mathrm{C}$ temperature and to this $10 \mathrm{ml} 5 \% \mathrm{CaCl}_{2}$ was immediately added with 20-25 drops of ammonia solution to restore yellow color. The solution after incubating overnight was filtered through ashless filter paper and washed several times. Along with residue the filter paper was dissolved in hot 1:5 $\mathrm{H}_{2} \mathrm{SO}_{4}$ and diluted to $125 \mathrm{ml}$. After heating to $90-100^{\circ} \mathrm{C}$ temperature, it was titrated against $0.05 \mathrm{NKMnO}_{4}$. Percent oxalate was calculated by using formula:

$$
\% \text { Oxalate }=\frac{m l \mathrm{KMnO}_{4} \text { used } \times 0.05 \times 45.02 \times 100}{1000 \times \text { dry weight } \times(50) / 100}
$$

Phytic acid was determined by the method described by Sadasivam and Manickam ${ }^{11}$ using the formula:

$\mu \mathrm{g} \mathrm{Fe}$ in sample $\times 15$

Phytate, Pmg/ 100g sample =

Weight of sample (g)

\section{Percentage yield of tofu}

Percentage yield of tofu was calculated as per

$$
\text { Wt. of dry matter in tofu g }
$$

Yield of tofu solid $\%=$

$$
\text { Wt. of dry matter in soybean } g
$$

\section{Sensory evaluation}

Sensory evaluation of the tofu prepared was performed for aroma, color, texture and appearance. For the sensory evaluation, ten semitrained panelist among the students and staff of National College of Food Science and Technology, Kathmandu, Nepal were participated. Composite Scoring test as suggested by Ranganna ${ }^{9}$ was adopted as a method of analysis. Aroma was rated 50, color and texture was rated 20 and appearance was rated 10 .

\section{Statistical data analysis}

Data were analyzed in triplicate and subjected to the analysis of variance (ANOVA) using the Statistical Analysis System using the Genstat program. Significant levels were defined as probabilities of 0.05 or $5 \%$ level of significant. Sample means were compared at $95 \%$ level of significance t-test by using Microsoft Office Excel 2007.

\section{Results and discussion}

\section{Effect of sprouting on chemical composition of soybean}

Soybeans after soaking for $12 \mathrm{hours}$ were germinated for $72 \mathrm{~h}$ with RH $90 \%$ in a RH Chamber. The samples were then subjected for analysis. The result obtained is presented in Table 1.

As shown in Table 1, moisture content was significantly increased ( $>0.05$ ) after germination. This finding is similar to the results reported by Khatoon and Prakash ${ }^{12}$ in germinated legumes (green Bengal and horse gram). The increase in moisture content of samples may be due to the hydration of samples. As the germination proceeds, legumes took up water from the surrounding in order for the metabolic process to commence. Dry legumes absorb water rapidly, influenced by the structure of the legume.

Protein content on the other hand increased considerably. Similar result was obtained by Onoja and Obizoba ${ }^{13}$ on some varieties of lima beans at $72 \mathrm{~h}, 96 \mathrm{~h}$ and $120 \mathrm{~h}$ of germination. Similarly, Mostafa and Rahma ${ }^{14}$ and Jimenez et al., ${ }^{15}$ reported increase in the percentage of protein in soybean during sprouting. Reverse of this, Rusydi et al., ${ }^{6}$ reported decrease in protein in soybean. The significant increase ( $>0.05)$ in crude protein content may be due to breakdown of complex protein molecules into simpler form and breakdown of nutritionally undesirable constituents. ${ }^{16}$

Crude fat content in the samples was determined and the obtained values were $20.53 \pm 3.54 \%$ and $13.62 \pm 0.63 \%$ for raw and germinated soybean respectively. The action of lipolytic enzymes may be the possible reason behind the decline of fat content. ${ }^{17}$ Blessing and Gregory ${ }^{18}$ also found similar reduction in fat content in mungbeans. The decrease in the fat could be attributed to the use of fat as an energy source to start germination.

Accordingly total ash content was determined and the obtained values were $4.56 \pm 0.45$ and $4.29 \pm 0.28$ for raw and germinated soybean respectively. The decrease was not so separable but was noticeable. Blessing and Gregory ${ }^{18}$ also reported decrease in total ash content of mungbean for 24 and 48 hours germination. Mostafa and Rahma ${ }^{14}$ also reported decrease in ash content of soybean. Total ash decreased may be due to soaking.

There was a significant increase $(p>0.05)$ in the crude fiber content. The obtained values for crude fiber of raw soybean was $5.75 \pm 0.62 \%$ and that of germinated was found to be $10.04 \pm 0.76 \%$. Jimenez et 
al. ${ }^{15}$ also reported increase in crude fiber content of soybean during germination. The increment may be due to the disappearance of starch and due to the synthesis of structural carbohydrates such as cellulose and hemicelluloses, a major constituent of cell walls. ${ }^{18}$

Carbohydrate was calculated by difference method for samples.
Carbohydrates content were found to be $31.41 \pm 0.74$ and $30.51 \pm 1.45 \%$ respectively for raw and germinated ones. Rusydi et al., ${ }^{6}$ reported decrease in carbohydrate content of soybean from $37.37 \pm 2.07$ to $17.99 \pm 3.33 \%$ on wet basis. This may be due to use of carbohydrate as a source of energy for embryonic growth.

Table I Chemical composition of raw and germinated soybean

\begin{tabular}{lclllll}
\hline Sample & Moisture\% & $\begin{array}{l}\text { Crude protein } \\
\%(\mathbf{d b})\end{array}$ & $\begin{array}{l}\text { Crude } \\
\text { fat\%(db) }\end{array}$ & $\begin{array}{l}\text { Total } \\
\text { Ash\%(db) }\end{array}$ & $\begin{array}{l}\text { Crude } \\
\text { Fibre\%(db) }\end{array}$ & Carbohydrate\%(db) \\
\hline NG & $10.33 \pm 0.37^{\mathrm{a}}$ & $37.72 \pm 3.73^{\mathrm{a}}$ & $20.53 \pm 3.54^{\mathrm{a}}$ & $4.56 \pm 0.45^{\mathrm{a}}$ & $5.75 \pm 0.62^{\mathrm{a}}$ & $31.41 \pm 0.74^{\mathrm{a}}$ \\
$\mathrm{G}$ & $57.16 \pm 0.34^{\mathrm{b}}$ & $41.43 \pm 0.94^{\mathrm{a}}$ & $13.62 \pm 0.63^{\mathrm{a}}$ & $4.29 \pm 0.28^{\mathrm{a}}$ & $10.04 \pm 0.76^{\mathrm{b}}$ & $30.51 \pm 1.45^{\mathrm{a}}$
\end{tabular}

*Values are means \pm standard deviation of triplicate determination, NG: Non-germinated soybean and G: Germinated soybean.

**Values followed by different superscript in the same column for different samples are significantly different $(p>0.05)$

\section{Effect of sprouting on proximate composition of tofu}

The result obtained for the triplicate determination is presented in Table 2.

Moisture content: Moisture content in the products were found to be $68.33 \pm 0.57 \%$ for regular tofu, $67.88 \pm 0.12 \%$ for sprouted tofu and $68.19 \pm 0.57 \%$ for combined tofu. These values are similar to the report of Shokunbi et al. ${ }^{19}$ However, it is lower than $82.84 \%$ reported by Shih et $a .^{20}$ The difference in moisture content may be due to variation in coagulants. The variation in moisture content is probably due to the difference in gel network within the tofu particles that is influenced by different anions and its ionic strengths towards the water holding capacity of soy protein gel. ${ }^{19}$

Crude protein: Crude protein content in the products was determined and the obtained values were $39.42 \pm 1.48 \%, 44.73 \pm 1.34 \%$ and $41.22 \pm 0.58 \%$ for regular tofu, sprouted tofu and combined tofu respectively. The values obtained for protein are lower than the values $(56.89-59.98 \%)$ obtained by Shokunbi et al., ${ }^{19}$ and $57.85 \%$ obtained by Oboh and Omotosho. ${ }^{21}$ These variations in protein content could be because of soybean variety used and the processing method adopted. Statistical analysis showed that there was significant difference among products ( $p>0.05$ ). These observations could be explained considering the fact that during sprouting, there is a breakdown of complex protein molecules into simpler form and breakdown of nutritionally undesirable constituents of soybean. ${ }^{16}$

Crude fat: Accordingly fat content was determined. There was significant difference among all the products $(p>0.05)$. The significant decrease in fat content of sprouted tofu may be due to the action of lipolytic enzymes during sprouting of soybean. ${ }^{17}$ The decrease in fat could be attributed to the use of fat as an energy source to start germination. The loss in total solids may impart the reduction in fat. Ghavidel and Prakash ${ }^{22}$ also concluded the similar results. Chavan and $\mathrm{Kadam}^{16}$ suggested decrease in fat content in germinated legumes. On the other hand, there is a significant increase in fat content of combined tofu. It may be due to decrease in crude protein content in the product.

Table 2 Compositional characteristic of tofu made from soybean, sprouted soybean and combination of both

\begin{tabular}{lllllll}
\hline Tofu & Moisture\% & $\begin{array}{l}\text { Crude } \\
\text { protein\%(db) }\end{array}$ & $\begin{array}{l}\text { Crude } \\
\text { Fat\%(db) }\end{array}$ & $\begin{array}{l}\text { Total } \\
\text { Ash\%(db) }\end{array}$ & $\begin{array}{l}\text { Crude } \\
\text { Fiber\%(db) }\end{array}$ & $\begin{array}{l}\text { Carbohydrate } \\
\%(\mathbf{d b})\end{array}$ \\
\hline Rt & $68.33 \pm 0.57^{\mathrm{a}}$ & $39.42 \pm 1.48^{\mathrm{a}}$ & $21.15 \pm 0.79^{\mathrm{a}}$ & $5.75 \pm 0.15^{\mathrm{a}}$ & $6.78 \pm 0.33^{\mathrm{a}}$ & $26.91 \pm 2.23^{\mathrm{a}}$ \\
$\mathrm{St}$ & $67.88 \pm 0.12^{\mathrm{a}}$ & $44.73 \pm 1.34^{\mathrm{b}}$ & $15.81 \pm 1.72^{\mathrm{b}}$ & $3.93 \pm 0.24^{\mathrm{b}}$ & $11.98 \pm 0.71^{\mathrm{b}}$ & $23.56 \pm 2.17^{\mathrm{a}}$ \\
$\mathrm{Ct}$ & $68.19 \pm 0.57^{\mathrm{a}}$ & $41.22 \pm 0.58^{\mathrm{ab}}$ & $20.23 \pm 0.46^{\mathrm{a}}$ & $4.16 \pm 0.19^{\mathrm{b}}$ & $9.78 \pm 0.63^{\mathrm{c}}$ & $24.61 \pm 0.99^{\mathrm{a}}$ \\
\hline
\end{tabular}

*Values are means \pm standard deviation of triplicate determination

**Values followed by same superscript in the same column for different products are not significantly different $(\mathrm{p} \leq 0.05)$

Rt, regular tofu; St, sprouted tofu; $\mathrm{Ct}$, combined tofu (NG+G: I:I) 
Total ash: Total ash content in the products was determined and the obtained values were $5.75 \pm 0.15 \%$ for regular tofu, $3.93 \pm 0.24 \%$ for sprouted tofu and $4.16 \pm 0.19 \%$ for combined tofu. Value obtained for regular tofu was in the range of 5.2-7.9\% reported by Obatolu. ${ }^{2}$ Statistical analysis showed that there was significant difference among regular tofu with sprouted and combined tofu but there was no significant difference $(\mathrm{p} \leq 0.05)$ between sprouted tofu and combined tofu.

Crude fiber: The increase in crude fiber of sprouted tofu and combined tofu may be due to disappearance of starch and synthesis of structural carbohydrates such as cellulose and hemicelluloses during sprouting of soybean. Blessing and Gregory ${ }^{18}$ also found drastic increment in cude fiber in germinated mungbeans.

Carbohydrate: Carbohydrate was calculated by difference method for products. There was no significant difference $(p \leq 0.05)$ among al the products. The decrease was not so separable but was noticeable. Decrease in carbohydrate content may be due to the synthesis of $\alpha$-amylase during germination of soybean, which breaks down complex carbohydrates to simpler and more absorbable sugars which are utilized by the growing seedlings during the early stages of germination. Blessing and Gregory ${ }^{18}$ also found similar decrease in carbohydrate content.

\section{Yield of tofu}

The percentage yield of regular tofu, sprouted tofu and combined tofu is presented in Table 3.

Table 3 Yield of tofu prepared from $200 \mathrm{~g}$ soybean

\begin{tabular}{lll}
\hline Tofu & Weight of tofu $(w b)$ & $\%$ Yield of tofu \\
\hline Rt & $239.78 \pm 0.546$ & $42.33 \pm 0.66^{\mathrm{a}}$ \\
St & $210.25 \pm 0.807$ & $37.69 \pm 0.55^{\mathrm{b}}$ \\
$\mathrm{Ct}$ & $221.09 \pm 0.707$ & $39.70 \pm 0.69^{\mathrm{c}}$ \\
\hline
\end{tabular}

*Data are expressed as mean \pm standard deviation, $\mathrm{n}=3$

**The differences between the values with same letter are non-

significant $(p>0.05)$ to each other within every parameter

Rt, regular tofu; St, sprouted tofu; $\mathrm{Ct}$, combined tofu (NG+G: I:I)

The yield of regular tofu, sprouted tofu and combined tofu was calculated on wet basis and dry basis as shown in Table 3. These outcomes are higher than 7.6-18.3\% reported by $\mathrm{Obah}^{23}$ and $18.30 \pm 2.14 \%$ reported by Yakubu and Aliyu. ${ }^{24}$ However Shokunbi et al., ${ }^{25}$ reported the yield of tofu as $66.25 \pm 0.48 \%$ coagulated from $\mathrm{CaCl}_{2}$. This may be due to difference in soybean varieties and the processing procedures.

From the statistical analysis, there was a significant difference between the products $(p>0.05)$. The decrement in yield of sprouted tofu may be due to the dry matter loss during soaking and sprouting which ranged from $7 \%$ to $13 \%{ }^{26}$ Dry matter loss is high during germination which could be the reason behind decrease in yield of tofu made from sprouted soybean.

\section{Result of sensory evaluation of tofu}

Sensory evaluation of different products was carried out to find out the best product through sensory evaluation. The main aim of sprouting was to decrease the beany odor in tofu. The products developed were evaluated on the basis of color, texture, aroma, and appearance. The results obtained by sensory evaluation are given in the Figure 1.

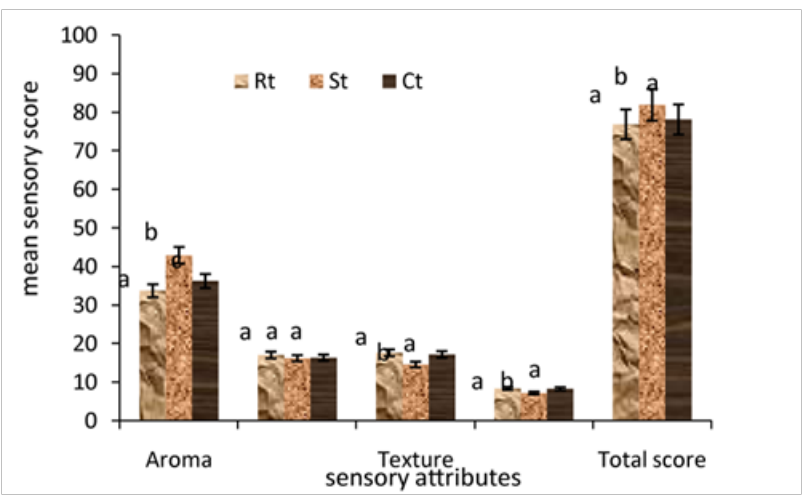

Figure I Comparative study of tofu prepared from germinated soybean, nongerminated soybean and combination of both on the basis of their sensory evaluation.

*The differences between the values with same letter are non-significant $(p>0.05)$ to each other within every parameter. Rt, regular tofu; St, sprouted tofu; $\mathrm{Ct}$, combined tofu (NG+G:I:I).

Aroma: The average sensory score of aroma for the Rt, St and $\mathrm{Ct}$ were $33.73,42.80$ and 36.27 respectively. The average values are presented in bar diagram in Figure 1. Statistical analysis shows that Rt, St and Ct were significantly different $(p>0.05)$ with each other at $5 \%$ level of significance.

Aroma was highly accepted in St and Ct as compared with Rt. It could be due to decrease in beany odor during sprouting of soybean. Sprouting is known to reduce undesirable flavors such as beany and grassy to a minimum and maximize total acceptability for the soymilk prepared from soybeans germinated for two days as well as in rotted nutty odor and taste. ${ }^{27}$ These results indicate that the sprouting of soybean could be done to reduce beany flavor in tofu.

Color: The average sensory score of color for Rt, St and Ct were $17.33,16.20$ and 16.33 respectively. The obtained mean values are presented in bar diagram in Figure 1. Statistical analysis shows that Rt, St and Ct were not significantly different $(\mathrm{p} \leq 0.05)$ at $5 \%$ level of significance. This showed that the color of sprouted tofu and combined tofu closely resembled that of regular tofu.

Texture: The average sensory score of texture for Rt, St and Ct were 17.67, 14.60 and 17.20 respectively. The obtained mean values are presented in bar diagram in Figure 1. Statistical analysis shows that $\mathrm{Rt}$ and $\mathrm{Ct}$ were significantly different $(\mathrm{p}>0.05)$ in texture with $\mathrm{St}$ at $5 \%$ level of significance. During sprouting, decrease in fat content and increased solubility of protein results in decrease in hardness of tofu.

Appearance: The average sensory score of appearance for Rt, St and Ct were 8.40, 7.20 and 8.33 respectively. The obtained mean values are presented in bar diagram in Figure 1. Statistical analysis shows that sample Rt and $\mathrm{Ct}$ were significantly different $(\mathrm{p}>0.05)$ in texture with $\mathrm{St}$ at $5 \%$ level of significance.

Total Score: The average total score for Rt, St and Ct were 76.87, 81.93 and 78.13 respectively. The obtained mean values are presented in bar diagram in Figure 1. Statistical analysis shows that Rt and Ct were not significantly different with each other $(\mathrm{p} \leq 0.05)$, however St showed 
significant difference with $\mathrm{Rt}$ and $\mathrm{Ct}$ at $5 \%$ level of significance. From Figure 1, St scored highest from the sensory analysis. This indicates that tofu prepared from sprouted soybeans was best among three products according to the result of sensory evaluation.

\section{Effect of coagulation temperature on yield of tofu}

The yield $\%$ of sprouted tofu and combined tofu prepared at two different temperatures, $75^{\circ} \mathrm{C}$ and $90^{\circ} \mathrm{C}$ is presented in Table 4 .

The yield $\%$ of sprouted tofu prepared by coagulating soymilk at $75{ }^{\circ} \mathrm{C}$ was found to be $37.39 \pm 0.589 \%$ and at $90^{\circ} \mathrm{C}$ was found to $45.74 \pm 0.271 \%$. Similarly, the yield $\%$ of combined tofu prepared by coagulating soymilk at $75^{\circ} \mathrm{C}$ and $90^{\circ} \mathrm{C}$ was found to be $38.91 \pm 0.685 \%$ and $45.756 \pm 0.512 \%$ respectively. There was a significant increase $(\mathrm{p}>0.05)$ in yield $\%$ of the samples. Coagulation temperature is another crucial factor in tofu making. The rate of soymilk coagulation and tofu quality are affected by the soymilk temperature. The lower yield at lower temperature may be due to poor water binding capacity of protein. Murdia and Wadhwani ${ }^{28}$ reported the optimum coagulation temperature for tofu is $90^{\circ} \mathrm{C}$.

Table 4 Percentage yield of tofu

\begin{tabular}{ll} 
Tofu & $\%$ Yield \\
\hline$A=$ Sprouted tofu coagulated at $75^{\circ} \mathrm{C}$ & $37.39 \pm 0.589^{\mathrm{a}}$ \\
$\mathrm{B}=$ Sprouted tofu coagulated at $90^{\circ} \mathrm{C}$ & $45.74 \pm 0.27 \mathrm{I}^{\mathrm{b}}$ \\
$\mathrm{C}=$ Combined tofu coagulated at $75^{\circ} \mathrm{C}$ & $38.91 \pm 0.685^{\mathrm{C}}$ \\
$D=$ Combined tofu coagulated at $90^{\circ} \mathrm{C}$ & $45.756 \pm 0.512^{\mathrm{b}}$ \\
\hline
\end{tabular}

*Data are expressed as mean \pm standard deviation (SD), $\mathrm{n}=3$

$* *$ Values followed by same superscript in the same column for different products are not significantly different $(p \leq 0.05)$

\section{Sensory analysis}

Sensory evaluation of different products was carried out to find out the best product through sensory evaluation. The products developed were evaluated on the basis of color, texture, aroma, and appearance. The results obtained by sensory evaluation are given in the Figure 2.

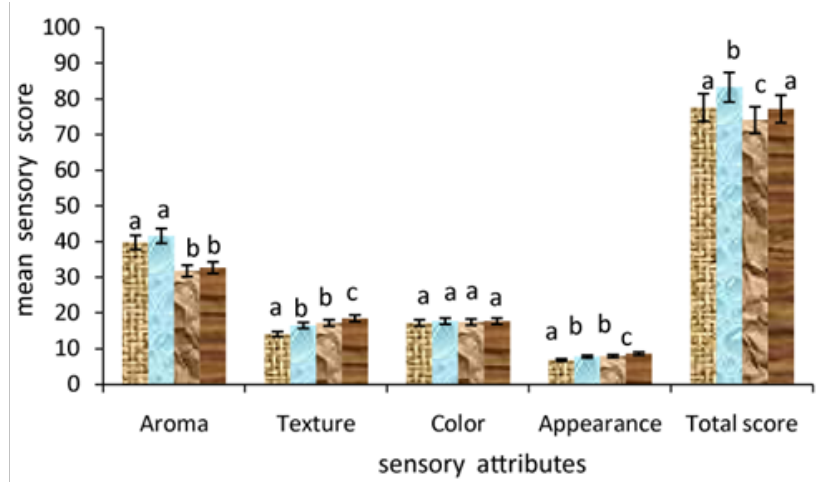

Figure 2 Effect of coagulation temperature in sensory attributes of tofu.

*The differences between the values with same letter are non-significant $(p>0.05)$ to each other within every parameter $A=$ Sprouted tofu coagulated at $75^{\circ} \mathrm{C} ; B=$ Sprouted tofu coagulated at $90^{\circ} \mathrm{C} ; \mathrm{C}=$ Combined tofu coagulated at $75^{\circ} \mathrm{C} ; \mathrm{D}=$ Combined tofu coagulated at $90^{\circ} \mathrm{C}$.

Aroma: The average sensory score of aroma for tofu A, B, C and D were $39.70,41.50,31.70$ and 32.60 respectively. The average values are presented in bar diagram in Figure 2. Statistical analysis shows that tofu A and B were significantly different with tofu C and D at 5\% level of significance. There was no significant difference $(p \leq 0.05)$ between sample A and B. Similarly, sample C and D were not significantly different $(\mathrm{p} \leq 0.05)$ in terms of aroma.

Aroma was highly accepted in tofu A and B as compared with tofu $\mathrm{C}$ and $\mathrm{D}$. It could be due to decrease in beany odor during sprouting of soybean. Increase in coagulating temperature slightly improved aroma between the samples. It may be due to decrease in beany flavour. ${ }^{29}$

Color: The average sensory score of color for tofu A, B, C and D were $17.10,17.60,17.40$ and 17.60 respectively. The obtained mean values are presented in bar diagram in Figure 1. Statistical analysis shows that tofu A, B, C and D were not significantly different ( $\mathrm{p} \leq 0.05)$ at $5 \%$ level of significance. This showed that the color of sprouted tofu and combined tofu closely resembled with each other. Similarly, increase in coagulating temperature did not make difference in color attribute of tofu.

Texture: The average sensory score of texture for tofu A, B, C and D were $14.00,16.40,17.10$ and 18.40 respectively. The obtained mean values are presented in bar diagram in Figure 1. Statistical analysis shows that tofu $\mathrm{B}$ and $\mathrm{C}$ were significantly different ( $\mathrm{p}>0.05$ ) in texture with tofu A and D at 5\% level of significance. During sprouting, decrease in fat content and increased solubility of protein results in decrease in hardness of tofu.

Texture was highly accepted in tofu B in comparison with tofu A and tofu D was highly accepted than tofu B. The microstructure of tofu is responsible for texture and depends on tofu composition and manufacturing processes. The firmness of tofu increased as temperature increased from $80^{\circ} \mathrm{C}$ to $90^{\circ} \mathrm{C} .^{28}$

Appearance: The average sensory score of appearance for tofu A, $\mathrm{B}, \mathrm{C}$ and $\mathrm{D}$ were $6.70,7.70,7.80$ and 8.50 respectively. The obtained mean values are presented in bar diagram in Figure 1. Statistical analysis shows that tofu $\mathrm{B}$ and $\mathrm{C}$ were significantly different $(\mathrm{p}>0.05)$ in appearance with tofu $\mathrm{A}$ and $\mathrm{D}$ at $5 \%$ level of significance.

Total Score: The average total score for tofu A, B, C and D were $77.50,83.20,74.00$ and 77.10 respectively. The obtained mean values are presented in bar diagram in Figure 1. Statistical analysis shows that tofu $A$ and $D$ were not significantly different $(p \leq 0.05)$ with each other, however tofu B and C showed significant difference ( $>0.05)$ with tofu A and D at 5\% level of significance. Tofu B had a highest total score while it was least for tofu C. This indicates that tofu prepared at coagulation temperature $90^{\circ} \mathrm{C}$ was best among all four products.

\section{Effect of coagulation temperature on chemical composition of tofu}

The result obtained for triplicate determination of proximate composition of tofu is presented in Table 5 .

Proximate composition: Moisture and fat decreased with increase in coagulation temperature from $75^{\circ} \mathrm{C}$ to $90^{\circ} \mathrm{C}$. Though there was not a significant difference among the samples, difference was noticeable. This could be due to volatilization of fat caused by heat during heating of soymilk. Conversely, crude protein, crude fiber and ash increased significantly $(p>0.05)$ with increased in processing temperature. This could be due to concentration effect. As the content of water and fat reduced from the tofu, the other components increased, thus improving the nutritional value of tofu.$^{30}$ Murdia and Wadhwani ${ }^{28}$ also obtained 
increase in protein content from $7.65 \pm 2.76 \%$ to $13.95 \pm 1.49 \%$ with increase in coagulation temperature from $80^{\circ} \mathrm{C}$ to $90^{\circ} \mathrm{C}$.

Calcium and Iron: The change in calcium and iron are significantly different $(p>0.05)$ for all the samples. There was a significant decrease $(\mathrm{p}>0.05)$ in calcium and iron content as coagulation temperature from $75^{\circ} \mathrm{C}$ to $90^{\circ} \mathrm{C}$. Bilgicli ${ }^{31}$ reported decrease in $\mathrm{Ca}$ and $\mathrm{Fe}$ contents from $227(\mathrm{mg} / 100 \mathrm{~g})$ and $2.98(\mathrm{mg} / 100 \mathrm{~g})$ to 198 and $5.9(\mathrm{mg} / 100 \mathrm{~g})$ in raw legumes and their bulgur produced by pressure cooking and oven drying at $80^{\circ} \mathrm{C}$. Soaking and cooking process caused considerable losses in soluble solids, especially vitamins and minerals. ${ }^{31}$

Table 5 Chemical composition of sprouted and combined tofu prepared at different coagulation temperature

\section{Coagulation temperature}

\begin{tabular}{|c|c|c|c|c|}
\hline Parameters & $\begin{array}{l}\mathrm{A}=\text { Sprouted Tofu } \\
\text { Coagulated at } 75^{\circ} \mathrm{C}\end{array}$ & $\begin{array}{l}\mathrm{B}=\text { Sprouted Tofu } \\
\text { Coagulated at } 90^{\circ} \mathrm{C}\end{array}$ & $\begin{array}{l}\mathrm{C}=\text { Combined Tofu } \\
\text { Coagulated at } 75^{\circ} \mathrm{C}\end{array}$ & $\begin{array}{l}\mathrm{D}=\text { Combined Tofu } \\
\text { Coagulated at } 90^{\circ} \mathrm{C}\end{array}$ \\
\hline Moisture (\%) & $68.43 \pm 0.57^{\mathrm{a}}$ & $67.97 \pm 0.25^{\mathrm{a}}$ & $69.21 \pm 0.67^{\mathrm{ab}}$ & $68.94 \pm 0.46^{\mathrm{a}}$ \\
\hline $\begin{array}{l}\text { Crude protein } \\
(\% \mathrm{db})\end{array}$ & $45.88 \pm 0.60^{\mathrm{a}}$ & $49.79 \pm 0.99^{b}$ & $41.59 \pm 0.67^{c}$ & $46.14 \pm 0.25^{\mathrm{a}}$ \\
\hline Crude fat (\%db) & $15.85 \pm 0.28^{a}$ & $15.70 \pm 0.57^{\mathrm{a}}$ & $20.24 \pm 0.28^{b}$ & $19.80 \pm\left. 0.3\right|^{b}$ \\
\hline Total ash (\%db) & $3.89 \pm 0.32^{\mathrm{a}}$ & $4.67 \pm 0.57^{b}$ & $4.43 \pm 0.13^{\mathrm{ab}}$ & $5.02 \pm 0.16^{b}$ \\
\hline Crude fiber (\%db) & $12.04 \pm 0.27^{\mathrm{a}}$ & $12.58 \pm 0.39^{\circ}$ & $9.30 \pm 0.20^{c}$ & $10.71 \pm 0.07^{d}$ \\
\hline $\begin{array}{l}\text { Carbohydrate } \\
\text { (\%db) }\end{array}$ & $22.33 \pm 0.99^{a}$ & $17.59 \pm 0.33^{b}$ & $24.36 \pm 0.50^{c}$ & $18.33 \pm 0.5 \mathrm{I}^{\mathrm{b}}$ \\
\hline Calcium (mg//00g) & $381.56 \pm 0.39^{a}$ & $351.25 \pm 0.49^{b}$ & $331.31 \pm 0.53^{c}$ & $302.15 \pm 0.64^{d}$ \\
\hline Iron (mg/l00g) & $7.47 \pm 0.16^{\mathrm{a}}$ & $3.33 \pm 0.18^{b}$ & $11.47 \pm 0.18^{c}$ & $7.50 \pm 0.18^{\mathrm{a}}$ \\
\hline
\end{tabular}

*Values are means \pm standard deviation of triplicate determination

**Values followed by same superscript in the same column for different products are not significantly different $(p \leq 0.05)$

\section{Changes in Anti nutritional factors}

Oxalate: The determined value for oxalate of tofu A, B, C and D were $0.017 \%, 0.014 \%, 0.021 \pm 0.001 \%$ and $0.015 \%$ respectively (Table 6 ). There was a significant difference $(\mathrm{p}>0.05)$ between tofu $\mathrm{A}$ and $\mathrm{B}$ and tofu $\mathrm{C}$ and $\mathrm{D}$. Increase in coagulation temperature lead to decreased oxalate content. ${ }^{32}$ Shokunbi et al., ${ }^{19}$ reported oxalate content to be $1.65 \mathrm{~g} / 100 \mathrm{~g}$. This decrease in oxalate may be due to germination of soybean. ${ }^{33}$ Khokhar and Apenten ${ }^{34}$ suggested the removal of oxalates to a safe level via germination. Similarly, there was a decrease in oxalate from tofu A to B and tofu $\mathrm{C}$ to $\mathrm{D}$. This may be due to increase in temperature of soymilk. Paul et al., ${ }^{35}$ also reported the average reduction of $24.9 \%$ oxalate in green pea and Bengal gram during cooking.

Phytic acid: The determined values for phytic acid of tofu A, B, C and $\mathrm{D}$ were $1.15 \pm 0.006,0.57 \pm 0.059,1.75 \pm 0.015$ and $1.15 \pm 0.006$ $(\mathrm{g} / 100 \mathrm{~g})$. There was a significant difference $(\mathrm{p}>0.05)$ between tofu A and tofu B, similarly between tofu C and D. Shokunbi et al., ${ }^{19}$ reported $2.23 \mathrm{~g} / 100 \mathrm{~g}$ phytate in regular tofu. This decrease in sprouted tofu may be due to germination of soybean which significantly reduces in phytate levels. Similarly, there was a decrease in phytic acid content from tofu A to tofu B and from tofu C to tofu D. Increase in temperature may be the reason behind it. Khan et al. ${ }^{36}$ reported loss of phytic acid from $18.1 \%$ to $46.7 \%$ for fresh maize and 11.5 to $52.6 \%$ for dry maize during heat processing of maize. 
Table 6 Changes in anti nutritional factors

\begin{tabular}{lll}
\hline Tofu & $\%$ Oxalate & Phytic acid g/l 00g \\
\hline A $=$ Sprouted tofu coagulated at $75^{\circ} \mathrm{C}$ & $0.017 \pm 0.000^{\mathrm{a}}$ & $1.15 \pm 0.0057^{\mathrm{a}}$ \\
$\mathrm{B}=$ Sprouted tofu coagulated at $90^{\circ} \mathrm{C}$ & $0.014 \pm 0.000^{\mathrm{b}}$ & $0.57 \pm 0.0585^{\mathrm{b}}$ \\
$\mathrm{C}=$ Combined tofu coagulated at $75^{\circ} \mathrm{C}$ & & $1.75 \pm 0.0152^{\mathrm{c}}$ \\
$\mathrm{D}=$ Combined tofu coagulated at $90^{\circ} \mathrm{C}$ & $0.021 \pm 0.00 \mathrm{I}^{\mathrm{c}}$ & $1.15 \pm 0.0057^{\mathrm{a}}$ \\
\hline
\end{tabular}

*Values are means \pm standard deviation of triplicate determination

$* *$ Values followed by same superscript in the same column for different products are not significantly different $(\mathrm{p} \leq 0.05)$

\section{Conclusion}

Germination results significant difference in proximate composition of soybeans. There was increase in protein content and decrease in crude fat content of sprouted tofu. There was a significant decrease in yield of sprouted tofu and combined tofu in comparison with regular one.

Sprouting helped in decrease of beany odor in tofu and was found to be best in terms of sensory analysis. Tofu prepared at $90^{\circ} \mathrm{C}$ coagulation temperature gave higher yield than that of prepared at $75^{\circ} \mathrm{C}$. There was decrease in fat and moisture and alternatively, increase in protein, ash and fiber with increase in temperature. Mineral content that is calcium and iron decreased with increase in temperature. Decrease in ANF was beneficial associated with germination and increase in coagulation temperature. Beany odor decreased with increase in coagulation temperature.

\section{Acknowledgements}

None.

\section{Conflict of interest}

Author declares that there is no conflict of interest.

\section{References}

1. Fukushima D. Soy protein for foods centering around soy sauce and tofu. J Am Oil Chem Soc. 1981;58(3):346-354.

2. Obatolu VA. Effect of different coagulants on yield and quantity of tofu from soymilk. Eu Food Res Technol. 2008;226(3):467-472.

3. Li J, Qiao Z, Tatsumi E, et al. A Novel Approach to Improving the Quality of Bittern Solidified Tofu by w/o Controlled-Released Coagulant in Tofu Processing \& Product Evaluation. Food and Bioprocess Technology. 2013;6(7):1801-1808.

4. Rekha CR, Vijayalakshmi G. Influence of processing parameters on the quality of soycurd (tofu). J Food Sci Technol. 2011;50(1):176-180.

5. Khattak AB, Zeb A, Bibi N, et al. Influence of germination techniques on phytic acid and polyphenols content of chickpea (Cicer arietinum L.) sprouts. J Food Chem. 2007;104(3):1074-1079.

6. Rusydi MMR, Noraliza CW, Azrina A, et al. Nutritional changes in germinated legumes and rice varieties. International Food Research Journal. 2011;18:705-713.
7. Kaushik G, Satya S, Naik SN. Effect of domestic processing techniques on the nutritional quality of the soybean. J Nutr Metab. 2010;3(1):39-46.

8. Murugkar DA. Effect of sprouting of soybean on the chemical composition and quality of soymilk and tofu. J Food Sci Technol. 2011;51(5):915-921.

9. Ranganna S. Handbook of Analysis and Quality Control for Products. New Delhi: Tata MCGraw-Hill Publishing Co. Ltd; 2008.

10. Patil UH, Gaikwad DK. Seasonal dynamics in the nutritional and antinutritional status of stem bark of Anogeissus lactofolia. Int J Biol Pharma Technol. 1968;2(1):373-374.

11. Sadasivam S, Manickam A. Anti-nutritional factors. In: "Biomedical Methods”. 3rd ed. New Delhi: New Age International Pvt. Ltd; 2008. p. 215-216.

12. Khatoon N, Prakash J. Nutrient retention in microwave cooked germinated legumes. Food Chem. 2006;97(1):115-121.

13. Onoja US, Obizoba IC. Effect of germination on nitrogen, lipids, total sugar and tannins content of lima bean varieties (Phaseolus lunatus L.). J Biomed Investigation. 2006;4(2):60-67.

14. Mostafa MM, Rahma EH. Chemical and nutritional changes in soybean during germination. Food Chem. 1987;23(4):257-275.

15. Jimenez MJ, Elias LG, Bressani R, et al. Biochemical and nutritional studies of germinated soybean seeds. Arch Latinoam Nutr. 1985;35(3):480-490.

16. Chavan JK, Kadam SS. Nutritional improvement of cereals by sprouting. Crit Rev Food Sci Nutr. 1989;28(5):401-437.

17. Frank OC, Catherine IC, Jude IC, et al. Investigation on the effect of germination on the proximate composition of African Yam Bean (Sphenostylis stenocarpa Hochst ex A Rich) and Fluted Pumpkin (Telferia occidentalis). J Appl Sci Environ Manang. 2009;13(2):59-61.

18. Blessing IA, Gregory IO. Effect of processing on the proximate composition of the dehulled and undehulled mungbean [Vigna radiata (L.) Wilczek] flours. Pakistan Journal of Nutrition. 2010;9(10):1006-1016.

19. Shokunbi OS, Babajide OO, Otaigbe DO, et al. Effect of coagulants on the yield, nutrient and anti-nutrient composition of tofu. Archives of Applied Science Research. 2011;3(3):522-527.

20. Shih MC, Yang KT, Kuo SJ. Quality and antioxidative activity of black soybean Tofu as affected by bean cultivar. J Food Sci. 2002;67(2):480-484. 
21. Oboh G, Omotosho OE. Effect of types of coagulant on the nutritive value and in vitro multienzyme protein digestibility of tofu. J Food Tech. 2005;3(2):182-187.

22. Ghavidel RA, Prakash J. The impact of germination and dehulling on nutrients, antinutrients, in vitro iron and calcium bioavailability and in vitro starch and protein digestibility of some legume seeds. J Food Sci Nutria. 2007;40(7):1292-1299.

23. Oboh G. Coagulants modulate the hypocholesterolemic effect of tofu (coagulated soymilk). African J Biotechnology. 2006;5(3):290-294.

24. Yakubu N, Aliyu OA. Effect of Different Types of Coagulants on the Nutritional Quality of Tofu produced in the Nothern Part of Nigeria. World Journal of Dairy \& Food Sciences. 2012;7(2):135-141.

25. Shokunbi OS, Babajide OO, Otaigbe DO, et al. Effect of coagulants on the yield, nutrient and anti-nutrient composition of tofu. Archives of applied science research. 2011;3(3):522-527.

26. Liang J, Han BZ, Nout MJ, et al. Effects of soaking, germination and fermentation oh phytic acid, total and in vitro soluble zinc in brown rice. J Food Chem. 2008;110:821-823.

27. Kim WJ, Yoon SK, Lee CY. Changes in oligosaccharides and sensory quality of soymilk during germination. Korean J Food Sci Technol. 1986;18(5):382-387.

28. Murdia LK, Wadhwani R. Effect of processing parameters on texture and yield of tofu. As J Food Ag-Ind. 2010;3(2):232-241.
29. Wang HL, Hesseltine CW. Coagulation conditions n tofu processing. Process Biochem. 1982;1:1808-1812.

30. Ikya JK, Gernah DJ, Ojobo HE, et al. Effect of cooking temperature on some quality characteristics of soy milk. Adv J Food Sci Technol. 2013;5(5):543-546.

31. Bilgici N. Effects of cooking and drying processes on physical, chemical and sensory properties of legume based bulgur. J Food Proc \& Pres. 2009;33(5):590-604.

32. Huisman J, Tolman GH. Antinutritional factors in the plant proteins of diet for non- ruminants. Recent Developments in Pig Nutrition. 2001;3:261-322.

33. Khan MA, Ghafoor A. The effect of soaking, germination and cooking on the protein quality of mash beans (Phaseolus mungo). J Sci Fd Agric. 1978;29:461-464.

34. Khokhar S, Owusu Apenten RK. Antinutritional factors in food legumes and effects of processing. In: The role of food, agriculture, forestry and fisheries in human nutrition. 4th ed. 2003:4-6.

35. Paul V, Verma S, Sushma, et al. Effect of cooking and processing methods on oxalate content of green leafy vegetables and pulses. As $J$ Food Ag-Ind. 2012;5(4):311-314.

36. Khan N, Zaman R, Elahi M. Effect of heat treatment on phytic acid content of maize products. J Sci Food Agric. 1991;54(1):153-156. 